\title{
Clinical presentation and in-hospital outcomes of older patients hospitalized with COVID-19 in Montreal, Canada: a retrospective review
}

Sandrine Couture, $\mathrm{MDCM}^{1^{*}}$, Marc-Antoine Lepage, MD MSc ${ }^{1^{*}}$, Claire Godard-Sebillotte, MD MPH $\mathrm{PhD}^{2}$, Nadia Sourial, $\mathrm{PhD}^{3,4}$, Catherine Talbot-Hamon, MD MSc (Epi) ${ }^{5}$, Richard Kremer, $\mathrm{MD} \mathrm{PhD}^{6}$, Ami Grunbaum, $\mathrm{MDCM}^{6}$

${ }^{1}$ Division of General Internal Medicine, McGill University Health Centre, Montreal, Canada

${ }^{2}$ Department of Family Medicine, McGill University, Montreal, Canada

${ }^{3}$ Département de médecine de famille et de médecine d'urgence, Université de Montréal, Montreal, Canada,

${ }^{4}$ Centre de recherche du Centre hospitalier de l'Université de Montréal, Montreal, Canada

${ }^{5}$ Division of Geriatric Medicine, McGill University Health Centre, Montreal, Canada

${ }^{6}$ Division of Medical Biochemistry, McGill University Health Centre, Montreal, Canada

*Sandrine Couture \& Marc-Antoine Lepage contributed equally to authorship of this manuscript.

\author{
Corresponding Author: \\ Ami Grunbaum \\ 1001 Boulevard Décarie - Glen Site, Montreal, QC, H4A 3J1 \\ Email: ami.grunbaum@mcgill.ca
}




\begin{abstract}
Background

Older adults are more vulnerable to severe infection and mortality due to COVID-19. They often have atypical presentations of the disease without respiratory symptoms, which makes early diagnosis clinically challenging. We aimed to compare the baseline characteristics, presentation, and disease course of older and younger patients hospitalized with COVID-19.

\section{Methods}

The charts of 429 consecutive patients hospitalized in Montreal, Canada, with PCRconfirmed COVID-19 were retrospectively reviewed. Baseline health, presentation, inhospital complications, and outcomes were recorded. Desegregation by age was performed to compare older $(\geq 70)$ versus younger $(<70)$ individuals.
\end{abstract}

\title{
Results
}

Older patients presented with more comorbidities compared to younger patients as captured by the Charlson Comorbidity Index (mean 6 vs 2), including higher rates of cardiovascular, cerebrovascular, chronic obstructive pulmonary, and chronic kidney disease. Older patients were less likely than younger patients to present with cough $(27 \%$ vs $47 \%)$ or dyspnea (33\% vs $48 \%)$. Fifty-two (52\%) had no respiratory symptoms on presentation compared to $32 \%$ in the younger group $(\mathrm{p}<0.001)$; however, they were more likely to present with geriatric syndromes such as delirium (29\% vs $7 \%)$, functional decline $(14 \%$ vs $0.6 \%)$, or falls $(15 \%$ vs $5 \%)$. Twelve $(12 \%)$ of older patients presented with a geriatric syndrome as their sole symptom compared to $3 \%$ in the younger group $(\mathrm{p}=0.002)$. Older adults were more likely to develop acute kidney injury (35\% vs $22 \%)$, malnutrition ( $9 \%$ vs 4\%), delirium (29\% vs 17\%) and hypernatremia (32\% vs 17\%). They had higher in-hospital mortality $(33 \%$ vs $13 \%, \mathrm{p}<0.001)$.

\section{Discussion}

Older adults presenting to hospital with COVID-19 commonly have no respiratory symptoms and can present with only a geriatric syndrome. A new geriatric syndrome in an older person should trigger isolation and evaluation for COVID-19. Furthermore, older adults are particularly vulnerable to complications related to dehydration, warranting early initiation of multidisciplinary care.

\section{INTRODUCTION}

Older adults are amongst the most vulnerable to severe infection and mortality due to COVID-19 (1-3). In Canada, as of January 2021, adults above age 70 accounted for 55\% of COVID-19 hospitalizations and $89 \%$ of deaths (4), while representing only $12 \%$ of the population (5). There is growing evidence that older adults are more likely to have atypical presentations of COVID-19 with lack of fever, cough, or dyspnea (6-8). Emerging reports suggest that COVID-19 may present as geriatric syndromes including falls and delirium in this population $(8,9)$. The nuances of the clinical presentation of older patients with COVID-19 has critical implications for the early diagnosis, timely isolation and infection control. An improved understanding of the disease course in older adults is crucial for enabling optimal care and prognostication in this high-risk population. To date, Canadian data is lacking with regards to clinical presentation, demographics, comorbidities and 
disease course of older adults hospitalized with COVID-19. The aims of this study are 1) to describe the clinical characteristics and outcomes of older persons $(\geq 70)$ hospitalized with COVID-19 at a tertiary hospital in Montreal during the first wave, 2) to determine whether older adults exhibit different presentations compared to younger patients $(<70)$ and 3) to determine whether older adults have different in-hospital course compared to younger patients. We hypothesized that non-respiratory presentations and geriatric syndromes would be more common in older adults, and that they would have higher mortality compared to younger patients.

\section{METHODS}

We conducted a retrospective review of electronic medical records of all patients age 18 and above with laboratory-confirmed COVID-19 admitted to the McGill University Health Centre (MUHC), a Montreal tertiary care hospital between March $26^{\text {th }}$ and July $16^{\text {th }}, 2020$. A confirmed case of COVID-19 was defined as a positive result of a real-time reversetranscriptase-polymerase-chain-reaction (RT-PCR) assay of a nasal swab specimen.

\section{Data Collection}

For each patient, the following data were extracted from electronic medical records: baseline demographic information, living situation, pre-existing medical conditions, home medications, clinical presentation, and disease course pre-hospitalization. The Charlson Comorbidity Index (10) was calculated using these baseline patient characteristics to capture the degree and severity of comorbidities in our cohort. We extracted laboratory and imaging findings at the time of admission, as well as complications, need for intensive care or ventilatory support, discharge destination or in-hospital death until July $16^{\text {th }}, 2020$, irrespective of the date of admission.

\section{Definitions}

Patients $\geq 70$ were classified as older patients; those $<70$ years old were classified as younger patients. We defined non-respiratory presentations as absence of cough, dyspnea, hemoptysis, sputum production, nasal congestion, and sore throat. In keeping with the American Geriatrics Society's recommendations to define geriatric syndromes as common conditions in older adults having significant consequences for functioning and quality of life (11), we considered falls, delirium and functional decline.

\section{Statistical Analysis}

Data was analyzed using IBM SPSS Statistics for Mac version 27.0 (SPSS Inc. Chicago, IL). Continuous variables are presented as means and standard deviations. Categorical variables are summarized as counts and percentages. We used the $\chi^{2}$ test to test our hypotheses that older patients would have more atypical presentations with lack of respiratory symptoms, geriatric syndromes, and higher mortality. All statistical tests were two-sided, and the differences were considered statistically significant at $\mathrm{p}<0.05$. 


\section{Ethics Approval}

MUHC institutional review board approval was obtained for data collection. All patient information was deidentified with respects to names, admission date and date of discharge or death.

\section{RESULTS}

\section{Population Characteristics and Medical Status at Baseline}

In total, 429 patients were hospitalized with PCR-confirmed COVID-19 at the MUHC between March $26^{\text {th }}$ and July $16^{\text {th }}, 2020$. Socio-demographic and baseline health characteristics of our cohort are presented in Table 1. Sixty-one percent (61\%) were aged 70 and above. Average age was 83 years old in the older group (standard deviation 7.31) and 55 in the younger group (standard deviation 11.71). Forty-nine percent $(49 \%)$ of patients in the older group and $37 \%$ in the younger group were women.

Older patients had more pre-existing medical conditions at baseline as captured by a higher mean Charlson Comorbidity Index of 6 compared to 2 in the younger group. These comorbidities included higher proportions of hypertension, coronary artery disease, heart failure, cerebrovascular disease, chronic obstructive pulmonary disease, chronic kidney disease (CKD), major neurocognitive disorder, and active cancers.

This higher proportion of comorbidities in the older group was reflected by a greater number of home medications compared to the younger group. Seventy-five percent $(75 \%)$ of patients in the older group had polypharmacy ( $>5$ medications) compared to $41 \%$ in the younger group.

Fifty-nine percent (59\%) of older patients originated from long-term care facilities and $32 \%$ were living at home in the community.

Table 1. Population Characteristics

\begin{tabular}{|c|c|c|}
\hline & Younger & Older \\
\hline & $\mathrm{N}=169$ & $\mathrm{~N}=260$ \\
\hline Age - mean (SD) & $55(11.7)$ & $83(7.3)$ \\
\hline \multicolumn{3}{|l|}{ Sex - no. (\%) } \\
\hline Male & $107(63)$ & $133(51)$ \\
\hline Female & $62(37)$ & $127(49)$ \\
\hline
\end{tabular}

\section{Home medications - no. (\%)}




\begin{tabular}{llc}
\hline 0 medication & $37(22)$ & $4(2)$ \\
\hline $1-5$ medications & $63(37)$ & $61(23)$ \\
\hline $6-10$ medications & $44(26)$ & $110(42)$ \\
$\geq 11$ medications & $25(15)$ & $85(33)$ \\
\hline $\begin{array}{l}\text { Charlson Comorbidity Index (CCI) - mean } \\
\text { (SD) }\end{array}$ & $2(2.1)$ & $6(2.1)$ \\
\hline
\end{tabular}

Past medical history - no. (\%)

Geriatric syndromes

\begin{tabular}{lcc}
\hline Fall(s) & $2(1)$ & $18(7)$ \\
\hline Dementia & $10(6)$ & $121(47)$
\end{tabular}

\section{Cardiovascular disease}

\begin{tabular}{llcc}
\hline & Hypertension & $79(47)$ & $171(66)$ \\
\hline & Heart failure & $7(4)$ & $53(20)$ \\
\hline Malignancy & Coronary artery disease & $17(10)$ & $62(24)$ \\
\hline & & & \\
\hline & Remote cancer & $5(3)$ & $32(12)$ \\
\hline & Active cancer & $6(4)$ & $24(9)$
\end{tabular}

\section{Endocrine disease}
Type 2 diabetes
$42(25)$
$87(33)$

\section{Pulmonary disease}

\begin{tabular}{llcc}
\hline & $\begin{array}{l}\text { Chronic obstructive } \\
\text { pulmonary disease }\end{array}$ & $12(7)$ & $59(23)$ \\
\hline Renal disease & & $14(8)$ & $53(20)$ \\
\hline & Chronic kidney disease & & \\
\hline $\begin{array}{l}\text { Neurological } \\
\text { disease }\end{array}$ & Parkinson's & $3(2)$ & $17(7)$ \\
\hline & Cerebrovascular disease & $6(4)$ & $48(18)$ \\
\hline $\begin{array}{l}\text { Hematological } \\
\text { disease }\end{array}$ & & & $10(3)$ \\
\hline
\end{tabular}




\begin{tabular}{llcc}
\hline $\begin{array}{l}\text { Living } \\
\text { situation }\end{array}$ & Home & $126(75)$ & $83(32)$ \\
\hline & $\begin{array}{l}\text { Autonomous private } \\
\text { residence }\end{array}$ & $4(2)$ & $22(8)$ \\
\hline & Long term care & $29(17)$ & $154(59)$ \\
\hline
\end{tabular}

\section{Clinical Presentation and Laboratory Abnormalities}

Older patients were less likely to present to hospital with respiratory symptoms of cough ( $27 \%$ vs $47 \%$ ) and dyspnea ( $33 \%$ vs $48 \%$ ) compared to their younger counterparts. Fiftytwo percent (52\%) of older patients presented without any respiratory symptoms compared to $32 \%$ of younger patients $(\mathrm{p}<0.001)$.

Older adults were more likely than younger patients to present with delirium ( $29 \%$ vs $7 \%)$, functional decline (14\% vs $1 \%)$, and falls (15\% vs $5 \%)$. Twelve percent $(12 \%)$ of older patients presented with a geriatric syndrome as their sole symptom compared to $3 \%$ of younger patients $(\mathrm{p}=0.002)$.

Table 2. Clinical Presentation

Younger Older p value

Presenting symptom(s) - no. (\%)

Asymptomatic $12(7) \quad 24(9)$

\section{Geriatric syndromes}

\begin{tabular}{cccc}
\hline Fall(s) & $9(5)$ & $39(15)$ & \\
\hline Delirium & $11(7)$ & $76(29)$ & \\
\hline Functional decline & $1(1)$ & $37(14)$ & \\
\hline $\begin{array}{l}\text { Geriatric syndrome(s) as the only } \\
\text { symptom }\end{array}$ & $5(3)$ & $30(12)$ & 0.002 \\
\hline
\end{tabular}

\section{Upper respiratory symptoms}

\begin{tabular}{lcc}
\hline Nasal congestion & $8(5)$ & $12(5)$ \\
\hline Sore throat & $11(7)$ & $5(2)$
\end{tabular}

\section{Lower respiratory symptoms}

\begin{tabular}{lcc}
\hline Cough & $80(47)$ & $69(27)$ \\
\hline Sputum production & $10(6)$ & $16(6)$ \\
\hline Hemoptysis & $2(1)$ & $1(0)$ \\
Dyspnea & $81(48)$ & $86(33)$ \\
\hline
\end{tabular}




\begin{tabular}{|c|c|c|c|}
\hline Respiratory symptoms alone & $22(13)$ & $32(12)$ & \\
\hline $\begin{array}{l}\text { Absence of respiratory symptoms } \\
\text { (upper and lower) }\end{array}$ & $54(32)$ & $134(52)$ & $<0.001$ \\
\hline \multicolumn{4}{|l|}{ Gastrointestinal symptoms } \\
\hline Anorexia (loss of appetite) & $14(8)$ & $46(18)$ & \\
\hline Nausea or vomiting & $14(8)$ & $15(6)$ & \\
\hline Diarrhea & $33(20)$ & $36(14)$ & \\
\hline Abdominal pain & $4(2)$ & $8(0)$ & \\
\hline $\begin{array}{l}\text { Gastrointestinal symptoms } \\
\text { alone }\end{array}$ & $4(2)$ & $6(2)$ & \\
\hline \multicolumn{4}{|l|}{ Other } \\
\hline Fatigue & $22(13)$ & $28(11)$ & \\
\hline General weakness & $25(15)$ & $48(18)$ & \\
\hline Subjective fever & $53(31)$ & $17(7)$ & \\
\hline $\begin{array}{l}\text { Objective fever }\left(\geq 38.3^{\circ} \mathrm{C} \times 1\right. \\
\left.\text { or } 38.0^{\circ} \mathrm{C} \times 2\right)\end{array}$ & $37(22)$ & $53(20)$ & \\
\hline Anosmia & $6(4)$ & $1(0)$ & \\
\hline
\end{tabular}

Ancillary laboratory and imaging findings on presentation are shown in Table 3 . The most common radiological findings at presentation for both the young and older groups were bilateral patchy opacities on chest x-ray.

Both groups had lymphopenia on presentation (absolute lymphocyte count $<1.0 \times 10^{9} / \mathrm{L}$ ). Older patients had lower CRP compared to the younger group (mean $104 \mathrm{vs} 133 \mathrm{mg} / \mathrm{L}$ ). The older group had higher baseline albumin than the younger group (mean 31 vs $34 \mathrm{~g} / \mathrm{L}$ ).

Table 3. Ancillary Findings on Presentation
Younger
Older

\section{Radiological findings \\ Chest X-ray findings - no. (\% of exam performed)}

\begin{tabular}{lcc} 
Normal & $27(18)$ & $40(17)$ \\
\hline Focal patchy opacity & $16(11)$ & $55(23)$ \\
Bilateral patchy opacities & $87(58)$ & $98(38)$ \\
Interstitial abnormalities & $28(19)$ & $58(22)$ \\
\hline Pleural effusion(s) & $1(1)$ & $12(5)$
\end{tabular}


Other findings
$5(3)$

$7(3)$

\section{Laboratory findings - mean (SD)}

\begin{tabular}{lcc}
\hline $\begin{array}{l}\text { White blood cell count }(4.5-11.0 \\
\left.\text { x } 10^{\wedge} 9 / \mathrm{L}\right) \mathrm{N}=426\end{array}$ & $7.5(3.64)$ & $7.5(3.83)$ \\
\hline $\begin{array}{l}\text { Absolute neutrophil cell count }(1.8-7.7 \\
\left.\text { x } 10^{\wedge} 9 / \mathrm{L}\right) \mathrm{N}=426\end{array}$ & $5.89(3.457)$ & $5.80(3.609)$ \\
\hline $\begin{array}{l}\text { Absolute lymphocyte cell count }(1.0- \\
\left.4.8 \times 10^{\wedge} 9 / \mathrm{L}\right) \mathrm{N}=426\end{array}$ & $0.98(0.542)$ & $0.97(0.574)$ \\
\hline $\begin{array}{l}\text { Platelet count }\left(140-150 \times 10^{\wedge} 9 / \mathrm{L}\right) \\
\mathrm{N}=426\end{array}$ & $222(99.6)$ & $205(86.6)$ \\
$\begin{array}{l}\text { Hemoglobin }(\text { women } 120-160, \mathrm{men} \\
135-175 \mathrm{~g} / \mathrm{L}) \mathrm{N}=426\end{array}$ & $129(22.1)$ & $126(21.1)$ \\
\hline $\begin{array}{l}\mathrm{C}-\text { reactive protein }(0.0-5.0 \mathrm{mg} / \mathrm{L}) \\
\mathrm{N}=177\end{array}$ & $133(108.2)$ & $104(84.6)$ \\
\hline $\begin{array}{l}\text { Lactate dehydrogenase }(110-220 \mathrm{U} / \mathrm{L}) \\
\mathrm{N}=135\end{array}$ & $374(228.2)$ & $1.79(1.279)$ \\
\hline $\begin{array}{l}\mathrm{D}-\text { dimer }(0.00-0.55 \mu \mathrm{g} / \mathrm{mL}) \mathrm{N}=123 \\
\text { Creatinine kinase }(24-195 \mathrm{U} / \mathrm{L})\end{array}$ & $1.52(1.054)$ \\
$\mathrm{N}=137$
\end{tabular}

\section{Complications and Outcomes}

Fifteen percent (15\%) of patients in the older group developed no complications from their disease compared to $44 \%$ in the younger group.

Older patients were more likely to develop delirium in hospital (30\% vs $17 \%)$, non-ST segment elevation myocardial infarction (NSTEMI) (13\% vs 7\%), malnutrition (9\% vs $4 \%$ ), acute kidney injury (AKI) (35\% vs $22 \%$ ), and hypernatremia ( $32 \%$ vs $17 \%)$.

As per institutional policy, goals of care were established at the time of hospitalization. Two hundred sixty-two (262) of 429 patients were eligible for intensive care unit (ICU) 
admission. Twenty-nine percent (29\%) of (? Eligible) older patients were cared for in the ICU, compared to $43 \%$ of younger patients.

In hospital mortality was higher in the older group ( $32 \%$ vs $12 \%, \mathrm{p}<0.001)$.

Table 4. Course in Hospital and Outcomes

\begin{tabular}{|c|c|c|c|}
\hline & Younger & Older & p value \\
\hline \multicolumn{4}{|l|}{ Complications - no. (\%) } \\
\hline None & $74(44)$ & $40(15)$ & \\
\hline \multicolumn{4}{|l|}{ Geriatric syndromes } \\
\hline Fall(s) & $3(2)$ & $7(3)$ & \\
\hline Delirium & $29(17)$ & $77(30)$ & \\
\hline Pressure injury & $3(2)$ & $10(4)$ & \\
\hline Malnutrition or denutrition & $6(4)$ & $24(9)$ & \\
\hline Deconditioning & $8(5)$ & $21(8)$ & \\
\hline \multicolumn{4}{|l|}{ Cardiovascular } \\
\hline NSTEMI or UA & $11(7)$ & $34(13)$ & \\
\hline STEMI & $12(7)$ & $34(13)$ & \\
\hline
\end{tabular}

\section{Renal and metabolic}

\begin{tabular}{lcc}
\hline AKI & $37(22)$ & $92(35)$ \\
\hline Hyponatremia $(<=128 \mathrm{mmol} / \mathrm{L})$ & $22(13)$ & $21(8)$ \\
\hline Hypernatremia $(>=148 \mathrm{mmol} / \mathrm{L})$ & $28(17)$ & $82(32)$ \\
\hline Rhabdomyolysis & $1(1)$ & $5(2)$ \\
\hline Transaminitis $($ ALT x3 UNL) & $21(12)$ & $13(5)$ \\
\hline
\end{tabular}

\section{Infectious}

\begin{tabular}{|c|c|c|}
\hline Clostridiodes difficile infection & $1(1)$ & $3(1)$ \\
\hline Septic shock & $8(5)$ & $6(2)$ \\
\hline Bacterial pneumonia superinfection & $30(18)$ & $44(17)$ \\
\hline \multicolumn{3}{|l|}{ Hematological } \\
\hline DIC & $1(1)$ & $2(1)$ \\
\hline Thrombocytopenia $\left(<100 \times 10^{\wedge} 9\right)$ & $19(11)$ & $41(16)$ \\
\hline \multicolumn{3}{|l|}{ VTE } \\
\hline $\mathrm{PE}^{* 1}$ & $7(4)$ & $5(2)$ \\
\hline DVT & $1(1)$ & $3(1)$ \\
\hline
\end{tabular}


*: definitive diagnose via CT-angio or V/Q scan at any point in time during admission

': Includes massive, hilar, segmental, and subsegmental PEs

\section{Intensive care and ventilatory support}

\begin{tabular}{lccc}
\hline $\begin{array}{l}\text { Admission to ICU if within goals of } \\
\text { care }(\mathrm{N}=262)\end{array}$ & $62(43)$ & $35(29)$ & \\
\hline $\begin{array}{l}\text { Intubation and mechanical ventilation } \\
(\mathrm{N}=262)\end{array}$ & $36(25)$ & $18(15)$ & \\
\hline $\begin{array}{c}\text { Outcome (at date cutoff) } \\
\text { Dean length of stay - } \\
\text { days (SD) }\end{array}$ & $19(19.0)$ & $21(14.6)$ & \\
\hline Discharged from hospital - no. (\%) & $21(12)$ & $84(32)$ & $<0.001$ \\
\hline $\begin{array}{l}\text { Mean length of stay - } \\
\text { days (SD) }\end{array}$ & $19(17.3)$ & $16(20.5)$ & \\
\hline
\end{tabular}

\section{DISCUSSION}

We report the characteristics, presenting features, and in-hospital outcomes of 429 COVID19 affected patients hospitalized at the MUHC in Montreal, Canada, with particular attention to those above age 70 . Patients $\geq 70$ differed from younger patients in their presentations. Over half of older adults lacked any respiratory symptoms. Their nonrespiratory presentations included geriatric syndromes of functional decline, fall, and delirium, which were the only symptoms in $12 \%$ of the older group. Older adults were more likely to develop delirium in hospital, cardiac complications, malnutrition, acute kidney injury, hypernatremia, and to die of their disease compared to patients younger than 70 .

The high rate of non-respiratory COVID-19 presentations in our study is concordant with recent reports from France and the United Kingdom where delirium and falls were common reasons for hospitalizations in patients above age 80 with $\operatorname{COVID-19}(8,9,12)$. Furthermore, given the high rate of patients from long-term care facilities in our study, our findings support the suggestion that non-respiratory presentations of COVID-19 are especially prominent in nursing home residents. This was shown in a single-center cohort study in the United Kingdom where $18.8 \%$ of patients from nursing homes had atypical symptoms, as well as in a point-prevalence survey in United States nursing homes where $8 \%$ of COVID-19 positive patients had atypical symptoms, defined in both studies as absence of fever, cough, or dyspnea $(9,13)$.

Our study does not reproduce the trend for elevated CRP and more profound lymphopenia in older adults on presentation compared to younger patients that was observed in China $(14,15)$. However, these studies use an age of 60 as cut-off to classify patients as elderly. Our results are more concordant with a study from the United Kingdom that showed no 
significant difference in inflammatory markers that used an age cut-off of 80 years old, which is closer to what would be defined as old age in Canada (9).

In addition, some older patients from our cohort were asymptomatic $(9 \%)$ or mildly ill and hospitalized for isolation reasons, as they were living in collective-dwellings. This may explain 1) their less profound laboratory abnormalities and 2) their lower likelihood to be admitted to ICU if within goals of care. This contrasts with findings of a study from China were higher rates of ICU admission were observed in patients $>60$ (14).

Older adults in our study were more likely to develop acute kidney injury and hypernatremia in-hospital compared to their younger counterparts. A French study of 821 patients hospitalized to Geriatric wards with COVID-19 similarly observed AKI as a frequent complication, which was significantly more frequent in older adults who died (16). The occurrence of these complications suggests a vulnerability of older adults hospitalized with COVID-19 to dehydration. Dehydration in older persons can have severe consequences. If left untreated, mortality can exceed $50 \%(17,18)$. Furthermore, it is a common precipitating factor for geriatric syndromes, including delirium and falls $(19,20)$. Cardiac complications were also more common in the older group. Of note, several of the NSTEMIs observed in our study population were classified by treating physicians as demand ischemia (type 2 NSTEMI) rather than plaque rupture, which may also suggest changes in volume status.

Our findings are consistent with previous studies that have demonstrated an association between older age and mortality $(3,7,21)$. However, our study may underestimate complications and mortality in the elderly population as multiple patients were discharged to community inpatient centers in order to offload acute care beds during the first wave of the pandemic in Montreal. We suspect multiple patients may have died in the community.

\section{Limitations}

Our study has limitations. First, the study only included patients within one center of the Montreal area (MUHC), but we included every patient, giving a comprehensive portrait in the most affected geographic area during the first wave of COVID-19 in Quebec. Second, the retrospective nature of the study required reliance on review of medical records for data extraction. Certain information was missing from baseline assessment, was based on other physicians' interpretation of findings, or relied on patients' recall of events. We only assessed short-term follow-up for all patients, limiting our assessment of long-term repercussions of the disease. Lastly, we performed statistical analyses for our pre-defined hypotheses regarding frequency of non-respiratory presentations, geriatric syndromes, and mortality. All other comparisons are descriptive. Caution should be taken regarding the reproducibility of the findings, with results viewed as hypothesis generating and to be validated in larger studies.

\section{Conclusion}

This is the first study reporting clinical presentation, in-hospital course, and outcomes of elderly patients hospitalized with COVID-19 in Canada. The data emphasizes the 
importance of non-respiratory presentations, and especially of geriatric syndromes as presenting features of COVID-19 in older adults. Our findings further demonstrate the heightened vulnerability of older adults to complications related to dehydration in hospital, emphasizing the need for early well-coordinated multidisciplinary care upon admission for this population.

\section{Implications for Practice}

- Beware of non-respiratory presentation of COVID-19 in older persons. An older person developing a new geriatric syndrome, in the context of the COVID-19 pandemic, should prompt early isolation and testing.

- When caring for older adults hospitalized with COVID-19, pay specific attention to evaluating and supporting proper hydration. Monitor closely for cardiac complications. 
medRxiv preprint doi: https://doi.org/10.1101/2021.02.27.21252596; this version posted March 1, 2021. The copyright holder for this preprint (which was not certified by peer review) is the author/funder, who has granted medRxiv a license to display the preprint in perpetuity.

\section{REFERENCES}

1. Fu L, Wang B, Yuan T, Chen X, Ao Y, Fitzpatrick T, Li P, Zhou Y, Lin YF, Duan Q, Luo G, Fan S, Lu Y, Feng A, Zhan Y, Liang B, Cai W, Zhang L, Du X, Li L, Shu Y, Zou H. Clinical characteristics of coronavirus disease 2019 (COVID-19) in China: A systematic review and meta-analysis. J Infect. 2020;80(6):656-65.

2. Onder G, Rezza G, Brusaferro S. Case-Fatality Rate and Characteristics of Patients Dying in Relation to COVID-19 in Italy. Jama. 2020;323(18):1775-6.

3. Imam Z, Odish F, Gill I, O'Connor D, Armstrong J, Vanood A, Ibironke O, Hanna A, Ranski A, Halalau A. Older age and comorbidity are independent mortality predictors in a large cohort of 1305 COVID-19 patients in Michigan, United States. J Intern Med. 2020;288(4):469-76.

4. Public Health Agency of Canada. Coronavirus Disease 2019 (COVID-2019). Daily Epidemiology Update. 2021.

5. Statistique Canada. Tableau 17-10-0005-01 Estimations de la population au 1er juillet, par âge et sexe. Lasted Updated 2020-05-30.

6. Leung C. Risk factors for predicting mortality in elderly patients with COVID-19: A review of clinical data in China. Mech Ageing Dev. 2020;188:111255.

7. Brill SE, Jarvis HC, Ozcan E, Burns TLP, Warraich RA, Amani LJ, Jaffer A, Paget S, Sivaramakrishnan A, Creer DD. COVID-19: a retrospective cohort study with focus on the over-80s and hospital-onset disease. BMC Med. 2020;18(1):194.

8. Annweiler C, Sacco G, Salles N, Aquino J-P, Gautier J, Berrut G, Guérin O, Gavazzi G, group obotSC-s. National French Survey of Coronavirus Disease (COVID-19) Symptoms in People Aged 70 and Over. Clinical Infectious Diseases. 2020.

9. Rawle MJ, Bertfield DL, Brill SE. Atypical presentations of COVID-19 in care home residents presenting to secondary care: A UK single centre study. Aging Med (Milton). 2020;3(4):237-44.

10. Frenkel WJ, Jongerius EJ, Mandjes-van Uitert MJ, van Munster BC, de Rooij SE. Validation of the Charlson Comorbidity Index in acutely hospitalized elderly adults: a prospective cohort study. J Am Geriatr Soc. 2014;62(2):342-6.

11. Inouye SK, Studenski S, Tinetti ME, Kuchel GA. Geriatric syndromes: clinical, research, and policy implications of a core geriatric concept. J Am Geriatr Soc. 2007;55(5):780-91.

12. Gan JM, Kho J, Akhunbay-Fudge M, Choo HM, Wright M, Batt F, Mandal AKJ, Chauhan R, Missouris CG. Atypical presentation of COVID-19 in hospitalised older adults. Ir J Med Sci. 2020:1-6.

13. Arons MM, Hatfield KM, Reddy SC, Kimball A, James A, Jacobs JR, Taylor J, Spicer K, Bardossy AC, Oakley LP, Tanwar S, Dyal JW, Harney J, Chisty Z, Bell JM, Methner M, Paul P, Carlson CM, McLaughlin HP, Thornburg N, Tong S, Tamin A, Tao Y, Uehara A, Harcourt J, Clark S, Brostrom-Smith C, Page LC, Kay M, Lewis J, Montgomery P, Stone ND, Clark TA, Honein MA, Duchin JS, Jernigan JA, Public H-S, King C, Team CC-I.

Presymptomatic SARS-CoV-2 Infections and Transmission in a Skilled Nursing Facility. The New England journal of medicine. 2020;382(22):2081-90.

14. Lian J, Jin X, Hao S, Cai H, Zhang S, Zheng L, Jia H, Hu J, Gao J, Zhang Y, Zhang X, Yu G, Wang X, Gu J, Ye C, Jin C, Lu Y, Yu X, Yu X, Ren Y, Qiu Y, Li L, Sheng J, Yang Y. 
medRxiv preprint doi: https://doi.org/10.1101/2021.02.27.21252596; this version posted March 1, 2021. The copyright holder for this preprint

(which was not certified by peer review) is the author/funder, who has granted medRxiv a license to display the preprint in perpetuity.

All rights reserved. No reuse allowed without permission.

Analysis of Epidemiological and Clinical Features in Older Patients With Coronavirus Disease 2019 (COVID-19) Outside Wuhan. Clin Infect Dis. 2020;71(15):740-7.

15. Liu K, Chen Y, Lin R, Han K. Clinical features of COVID-19 in elderly patients: A comparison with young and middle-aged patients. J Infect. 2020;80(6):e14-e8.

16. Zerah L, Baudouin É, Pépin M, Mary M, Krypciak S, Bianco C, Roux S, Gross A, Toméo $C$, Lemarié N, Dureau A, Bastiani S, Ketz F, Boully $C$, de Villelongue $C$, Romdhani M, Desoutter MA, Duron E, David JP, Thomas C, Paillaud E, de Malglaive P, Bouvard E, Lacrampe M, Mercadier E, Monti A, Hanon O, Fossey-Diaz V, Bourdonnec L, Riou B, Vallet $\mathrm{H}$, Boddaert J. Clinical Characteristics and Outcomes of 821 Older Patients with SARS-Cov-2 Infection Admitted to Acute Care Geriatric Wards. J Gerontol A Biol Sci Med Sci. 2020.

17. Mahowald JM, Himmelstein DU. Hypernatremia in the elderly: relation to infection and mortality. J Am Geriatr Soc. 1981;29(4):177-80.

18. Weinberg AD, Minaker KL. Dehydration. Evaluation and management in older adults. Council on Scientific Affairs, American Medical Association. Jama. 1995;274(19):1552-6.

19. Hamrick I, Norton D, Birstler J, Chen G, Cruz L, Hanrahan L. Association Between Dehydration and Falls. Mayo Clin Proc Innov Qual Outcomes. 2020;4(3):259-65.

20. Oh ES, Fong TG, Hshieh TT, Inouye SK. Delirium in Older Persons: Advances in Diagnosis and Treatment. Jama. 2017;318(12):1161-74.

21. Zhou F, Yu T, Du R, Fan G, Liu Y, Liu Z, Xiang J, Wang Y, Song B, Gu X, Guan L, Wei Y, Li H, Wu X, Xu J, Tu S, Zhang Y, Chen H, Cao B. Clinical course and risk factors for mortality of adult inpatients with COVID-19 in Wuhan, China: a retrospective cohort study. Lancet (London, England). 2020;395(10229):1054-62. 